\title{
The impact of Corporate Governance Mechanisms on Firm Value
}

\author{
Elvi Yanti ${ }^{1}$, Dina Patrisia ${ }^{2}$ \\ ${ }^{1}$ Universitas Negeri Padang, Padang, Indonesia, $\bowtie$ elvi96.yanti@gmail.com \\ ${ }^{2}$ Universitas Negeri Padang, Padang, Indonesia, $₫$ patrisiadina@yahoo.com
}

\begin{abstract}
This study aims to analyze the effect of board size, independent board, audit committee, and institutional ownership on firm value. The population of this research is 539 companies which are registered in Indonesia Stock Exchange. By using purposive sampling method, we used 242 companies which are listed from 2013 to 2017. The analysis technique is multiple linear regression analysis. The results show that the size of director board, independent board, audit committee, and institutional ownership have positive and significant impacts on firm value

Keywords: board size, independent board, audit committee, institutional ownership, and firm value.
\end{abstract}

\section{Introduction}

Corporate governance becomes an important issue in emerging countries such as Indonesia. There are several financial statement manipulation cases have been recorded in Indonesia. Boediono (2005) says that several cases in Indonesia such as PT. Lippo Tbk and PT Kimia Farma Tbk also involve in financial reporting detection of manipulation indication. Poor corporate governance, weak of investor relations, lack level of transparency, inefficiency in the financial statements, and the lack of law enforcement to punish perpetrators and protect the minority shareholders to be trigger and reasons behind why some companies in Indonesia collapsed (Boediono, 2005),

To improve company performance, the company itself needs to have main goal, according to the corporate theory, the company's main goal is to maximize wealth or firm value (Salvatore, 2011). According to Harmono (2009) states that firm value is company's performance, which is reflected in the share price set by market demand and supply of capital that reflects the public's assessment of company performance. This study uses measuring of firm value instrument namely Tobin's q.

According to Gul et al (2012), company will be faced with more serious problems if it has weak corporate governance structure, although managers maximize firm value, but it was all done to satisfy personal interests and not to maximize shareholder value. Corporate governance in accordance with the Corporate Governance forum in Indonesia (FCGI, 2001) is set of rules that govern the relationship between shareholders, board, corporate managers, creditors, government, employees, as well as internal and other external stakeholders related to the rights and obligations or in other words a system used to control company.

Corporate governance, which is a concept based on theory, expected to be used to notify investors that they would receive funds they have invested. In Agency Theory, Jensen and Meckling (1976) state that to make good corporate governance for company, it is expected to reduce agency conflict. To improve enterprise performance and reduce the agency conflict, corporate governance mechanisms needs to be set up by company that will implement it in the form of director board, independent board, managerial ownership, institutional ownership, and audit committee. According to Veronica (2005), several mechanisms of corporate governance is manifested by board of directors, audit committees, audit quality and institutional ownership. From some of these mechanisms, this study will be focused on four mechanisms that are considered essential for any company to establish a better corporate governance, namely independent board, the size of director board, audit committee, and institutional ownership. 
The first corporate governance mechanism is board size. According to Fama (1983), The board of commissioners is the highest internal control mechanism that is responsible for monitoring the actions of top management. According to National Committee on Governance (2006), board of commissioners as company organ in charge and is collectively responsible for overseeing and advising the Board of Directors as well as ensure that the company implements the GCG. According to Coller (1999) and Sembiring (2006) the greater number of commissioners, the easier it is to control the Chief Executives Officer (CEO) and more effective in monitoring the management activities. Research conducted Abdullah et al (2008), Dalton (1999), Siallagan (2006), stating board size effect on corporate performance by measuring Tobin's q. In contrast a study conducted by Mak and Kusnadi (2005), Detthamrong, Chancharat, and Vithessonthi (2017), state that the board size does not affect the firm values.

The second corporate governance mechanism is independent commissioner. According to National Committee on Governance (2006), independent directors are board members who are not affiliated with management, other members of directors board and controlling shareholders, as well as free from the business relationship or other relationship that could affect their ability to act independently or act solely in the company interest. Independent board has the primary responsibility to promote the application of the corporate governance principles within company through the empowerment of independent board to perform monitoring task and advising director board effectively and provide added value to corporate. In Indonesia Regulation Bank No. 8 / 4 / PBI / 2006, the proportion of independent board at least 50\% (fifty percent) of the number of commissioners. The proportion of commissioners can make an effective contribution to process outcome of preparing financial statements which are qualified or the possibility to avoid fraudulent financial statements. According to Connelly (2017), Abbasi, (2012), Dung (2011) OuYang (2008) that there is a positive influence on independent members proportion of the Board Commissioner on firm value. In contrast with a study conducted by Agrawal \& Knoeber (1996), Detthamrong, Chancharat, and Vithessonthi (2017) reveal that independent commissioner has significantntly negative effect on firm value.

The third corporate governance mechanism is audit committee. According to Indonesian Institute of Audit Committee (2009), The Audit Committee is a committee that works professionally and independently established by director board, thus task is to assist and strengthen the functions of director board (supervisory) in the financial reporting process aspect, risk management, audit and implementation procedures corporate governance in company. The audit committee provides insight into accounting problem, financial reporting and explanation, internal control system as well as independent auditors in a company. Thus, the audit committee has a very important role and strategic in terms of maintaining the credibility of financial reporting process and to maintain adequacy creation. According to Louis (2004), the audit committee has an important role in corporate governance. The audit committee is responsible for monitoring companies' activities of financial reporting system. Company surveillance system and good corporate governance implementation. A study conducted by Onasis (2016), Gill \& Obradovich (2012) and Rouf (2011) and Tornyeva (2012) which state that the audit committee variables have significant positive effect on firm value. Results of research by Aldamen (2012), Detthamrong (2017), indicate that the audit committee did not significantly affect firm value.

The fourth corporate governance mechanism is institutional ownership. According to agency theory which states that institutional ownership is monitoring agents having role to provide oversight focused on the managerial side through watchdogs to proportionate share of each institution in a company (Firdausya et al 2013). Maug (1998), Cornett et al, (2007), state that institutions affect the company's decision on the size of the stake that they have. If high institutional ownership, then there is an attempt to monitor management, but if not investors institutions can easily wirhdraw shares if company performs poorly. The study results obtained by Slovin \& Sushka (2007) state that corporate value will increase if institutional owner can be quite effective monitoring tool. Shareholdings by institutions or certain institutions are proven to increase corporate value (Shleifer, 1986). A study by Chen et al (2008) express 
positive influence ownership institutional value of a corporate. Different studies conducted by Syafitri, Nuzula, Nurlaily (2018), and Afnan \& Rahardja (2014) state that there is a negative significant between institutional ownership on firm value.

Based on the above background, researchers is very keen to conduct research entitle The Impact of Corporate Governance Mechanism on Firm Value.

\section{Methods}

This research focuses on effect board size, independent board, audit committee, and institutional ownership on corporate value. The population of this research is companies registered in the Indonesia Stock Exchange accounting 539 companies sample and uses purposive sampling method in order to obtain 242 sample listed in Indonesia Stock Exchange in 2013 to 2017. The analysis technique used is multiple linear regression analysis.

\section{Results and Discussion}

Multiple linear regression analysis is used to determine the effect of independent variables board size, independent board, audit committee, and institutional ownership on firm value listed in Indonesia Stock Exchange. From data processing with SPSS 16.0, obtained result as in the following table:

Table 1 Results of Multiple Linear Regression Analysis

\begin{tabular}{lllllll}
\hline Variables & $\begin{array}{l}\text { The } \\
\text { regression } \\
\text { coefficient }\end{array}$ & $\mathbf{t}$ & sig. & $\begin{array}{l}\boldsymbol{R} \\
\text { square }\end{array}$ & F count & Sig \\
\hline & B & & & & & \\
\hline & & 5,858 & .000 & 0.056 & 17902 & .000 \\
\hline (Constant) & .191 & 6789 & .000 & & \\
\hline The size of the BOC (X1) & .106 & 3,757 & .000 & & \\
\hline $\begin{array}{l}\text { Independent Commissioner Board } \\
(\mathrm{X} 2)\end{array}$ & .082 & 2,798 & .005 & & \\
\hline Audit Committee (X3) & .070 & 2,399 & .017 & & \\
\hline Institutional Ownership (X4) & & &
\end{tabular}

Source: Processed results of SPSS Statistics 16.0, 2019

From the table above can be specified multiple regression equation as follows:

$$
\begin{aligned}
& \text { Yit }=\beta \mathrm{o}+\beta 1+\beta 2 \text { X1it X3it X2it }+\beta 3+\beta 4 \text { X4it + e } \\
& Y=5,858+6,789 X 1+3,757 X 2+2,798 X 3+2,399 X 4
\end{aligned}
$$

Where :

$\begin{array}{ll}\text { YIT } & =\text { firm value }(\text { Tobin's Q) } \\ \beta 0 & =\text { constant } \\ \beta 1-\beta 2-\beta 3-\beta 4 & =\text { regression coefficient } \\ \text { X1it } & =\text { size board of commissioners } \\ \text { X2it } & =\text { BOC Independent } \\ \text { X3it } & =\text { the Audit Committee } \\ \text { X4it } & =\text { institutional ownership } \\ \text { E } & =\text { error }\end{array}$

Based on the regression equation above, it can be interpreted as follows:

1. The magnitude of constants obtained accounting 5,858, it shows without any independent variables as commissioners board size (X1), independent board (X2), audit committee (X3), and institutional ownership (X4), then firm value (Y) of 3.599. 
2. The regression coefficient (b) of board size variable (X1) obtained is positive accounting 6.789 indicates that any increase in the number of members board size as much as one person, it will result in an increase of firm value which is equal to 6.789 .

3. The regression coefficient (b) of independent board variable (X2) obtained is positive, accounting 3.757 indicates that any increase in variable independent board as much as one percent, it will result in an increase of firm value amounting to 3,757 .

4. The regression coefficient (b) of audit committee variable (X3) obtained is positive, accounting 2.798 indicates that any increase in variable audit committee as much as one, it will result in an increase of firm value which is equal to 2.798 .

5. The regression coefficient (b) of institutional ownership variable (X4) obtained is positive, accounting 2.399 indicates that any increase in institutional ownership variable one-time, it will result in an increase on firm value which is equal to 2.399 .

\section{Feasibility Test}

Based on Table 1 above, obtained F accounting 17.902 with sig $0.000<0.05$. This means that F test conducted jointly with independent variables whose positive influence and significant impact on corporate value listed in Indonesia Stock Exchange, which means that independent variables has a positive and significant effect on dependent variable.

The coefficient of determination is needed to see how big the contribution of the dependent variable $(\mathrm{X})$ on the independent variable $(\mathrm{Y})$. The calculations obtained by squaring the correlation coefficient has been determined. Based on Table 1 contribution variable board size, independent board, audit committee, and institutional ownership on firm value companies listed in Indonesia Stock Exchange accounting $5.6 \%$, and the remaining $94.4 \%$ variable of corporate value granted by other unidentified factors as profitability ratios, liquidity ratios, activity ratios, and the ratio of the market.

\section{Hypothesis Testing}

Hypothesis 1

Board size has significantly positive effect on firm value listed in Indonesia Stock Exchange. Based on results analysis test, it is known that significant value of $0.000>0.05$, meaning $\mathrm{H} 0$ is rejected and Ha is accepted, so alternative hypothesis proposed in the study is accepted, that the board size has significantly positive effect on firm value listed in Indonesia Stock Exchange.

Hypothesis 2

Independent board has positive and significant effect on firm value as listed in Indonesia Stock Exchange. Based on results analysis test shows significant value of $0.000>0.05$. It means $\mathrm{H} 0$ is rejected and $\mathrm{Ha}$ is accepted, so alternative hypothesis proposed in the study is accepted, that the independent board positive has significant effect on firm value as listed in Indonesia Stock Exchange.

Hypothesis 3

The audit committee has significant positive effect on firm value as listed in Indonesia Stock Exchange. Based on test results analysis, it shows a significant value of $0.005>0.05$, which means that $\mathrm{H} 0$ is rejected and Ha is accepted, so alternative hypothesis proposed in the study is accepted, that audit committee has significant positive effect on firm value as listed in Indonesia Stock Exchange.

\section{Hypothesis 4}

Institutional ownership has significant positive effect on firm value as listed in Indonesia Stock Exchange. Based on analysis result test, it shows significant value of $0.017>0.05$, which means that $\mathrm{H} 0$ is rejected and Ha is accepted, so alternative hypothesis proposed in the study is accepted, that institutional ownership has significant positive effect on firm value as listed in Indonesia Stock Exchange.

\section{The Impact of Commissioners Board Size on Corporate Value}


Based on hypothesis result testing, it is found that size board has significant positive effect on firm value as listed in Indonesia Stock Exchange. This means that director board size determines firm value as listed in Indonesia Stock Exchange. From the research results, it can be clearly seen thath board size coefficient accounting 6.789 and has no effect or positive direction to firm value. The results show that increasing number of board members will increase firm value as listed in Indonesia Stock Exchange.

In agency theory perspective, the commissioners represent the main internal mechanism to control the opportunistic behavior of management that can help align the interests of shareholders and managers (Anggraeni, 2013). According to study conducted by Dalton and Dalton (2005), Abdullah et al (2008), Siallagan and Machfoedz (2006), Kiel and Nicholson (2003), Adams and Mehran (2005), reveal commissioners have direct relationship with firm value as well as a significant impact.

The Impact of Independent Commissioner Board on Firm Value

Based on the hypothesis testing result, it is found that the independent board has positive and significant effect on firm value as listed in Indonesia Stock Exchange. This means that the independent board can determine corporate value. From the study results, it can be seen independent board coefficient accounting 3.757 and has no effect or positive direction to corporate value. This result indicates that the more increase of independent board percentage, the more firm values.

This research is supported by agency theory, that the greater number of director board independent, the better the supervision and control of executive director actions. In research conducted by Abbasi et al. (2012), To Thi Dung (2011), Ou-Yang (2008), Hermalin and Weisbach (1991), Bhagat and Black (2002), Onasis (2016) state that there is a positive influence on commissionair board members proportion independently on firm value.

\section{The Impact of Audit Committee on Firm Value}

Based on hypothesis testing result, it is found that audit committee has significantly positive effect on firm value as listed in Indonesia Stock Exchange. This means that audit committe can determine firm value. It can be clearly seen from the result of this study the coefficient of audit comittee at 2,798 and it has postive effect on firm value. The result indicates that there is an increasing of amount of audit committee meeting, and it will encourage the improvement of firm values.

This research is supported by agency theory, companies whose high value tend to have completeness in its composition structure as the existence of an audit committee (Afnan and Rahardja, 2014), Siallagan (2006) state that the existence of audit committee positively affect the firm value. A study conducted by Saifi \& Sarafina (2017) states that the audit committee significantly influences on Tobin's Q. A study by Onasis (2016), Raghunandan and Rama (2007), Sharma et al (2009), Gill \& Obradovich (2012) and Rouf (2011), Josephine, Zakaria, and Godfrey (2016) and Tornyeva (2012) state that the audit committee variables have significant and positive effect on firm value.

\section{The Impact of Institutional Ownership on Firm Value}

Based on hypothesis testing result, it is found that institutional ownership has positive and significant effect on firm value as listed in Indonesia Stock Exchange. This means that institutional ownership can determine corporate value. From the research results, it can be clearly seen that coefficient of 2.399 and institutional ownership has effect and positive direction to firm value. The results show that the more increasing institutional ownership obtained, it will boost corporate values a lot.

This research is supported by agency theory stating that institutional ownership as monitoring agents who have role to provide oversight focused on the managerial side through supervision focused on proportionate share of each institution in a company (Firdausya et al 2013). A research by Chen et al. (2008) reports there is a positive influence between ownership institutional and corporate value. Institutional investors can contribute positively in monitoring the behavior management. The results obtained by Slovin \& Sushka (2007) which indicates that firm value will increase if institution owner can 
be a quite effectively monitoring tools. Research conducted by Aggarwal (2006), Brown and Caylor (2006), Khurram Khan (2011),Li Lin (2010), Navissi (2006) also reveal that institutional ownership provides a significant and positive impact on firm value.

\section{Conclusion}

Based on the analysis and discussion about board size, independent board, audit committee, and institutional ownership on firm value as listed in Indonesia Stock Exchange. On conclusion note, among board size, independent board, audit committee, and institutional ownership have positive and significant impact firm value as listed in Indonesia Stock Exchange.

\section{References}

Abbasi, M. et al. (2012). Impact of Corporate Governance Mechanism on Firm Value: Evidence From The Food Industry in Iran. Journal of Basic and Applied Scientific Research, 5 (2), 4712-4721.

Abdullah, MS, PhD., SZA, Shah, PhD., AH (2008). Impact of Corporate Governance on Financial Performance of Firms: Evidence from Pakistan. The Business Review, Cambridge, 11 (2), 282-289.

Adams, RB and Mehran, H. (2005). Corporate performance, board structure and its determinants in the banking industry (paper presented at the EFA Annual Meeting). Moscow.

Afnan, A., \& Rahardja, R. (2014). Size Effect of BOC, and the proportion of Independent Commissioner Against Financial Performance by Profit Management as an intervening variable. Diponegoro Journal of Accounting, 3 (3), 1.

Aggarwal, R., and R. Williamson. (2006). Did the new regulations target of the relevant corporate governance attributes? Working Paper, Georgetown University.

Agrawal, A. and CRK (1996). Firm Performance and Mechanism to Control Agency Problems Between Managers adn Shareholders. Journal of Financial and Quantitative Analysis, 31, 377-397.

Al, G. et. (2012). Agency Cost, Corporate Governance and Ownership Structure (The Case of Pakistan). International Journal of Business and Social Science, 3 (9), 268-277.

Aldamen, H., Duncan, K., Kelly, S., Namara, RM, \& Nagel, S. (2012). The Audit Committee and Firm Performance Characteristics During Global Finance Crisis. Accounting and Finance, (52) 971-1000.

Anggraeni, RMDPBH (2013). Effect of Managerial Ownership Structure, Company Size, And Corporate Governance Practices Against Profit Management. Diponegoro Journal of Accounting, 2 (3).

Bhagat, S and Bolton, B. (2002). The non-correlation between board independence and long-term firm performance. Journal of Corporation Law, 27 (2), 231-274.

Boediono, GS (2005). Quality of Earnings: The Effect Study of Corporate Governance Mechanisms and Impact of Earnings Management by Using Path Analysis. Accounting National Symposium VIII, VIII (September), 172-194.

Brown, LD and Caylor, M.. (2006). Corporate governance and firm valution. Journal of Accounting and Public Policy, 25 (4), 409-434.

Chen, J., L. Blenman, DHC (2008). Institutional Ownership does Create Values? The New Zealand Case. Quarterly Journal of Finance and Accounting, 47 (4), 109-124.

Coller, P., and AG (1999). "Activity of the Audit Committee and Agency Costs." Journal of Accounting and Public Policy, 18 (4-5), 311-332.

Connelly, JT, Limpaphayom, P., Nguyen, HT, \& Tran, TD (2017). A Tale of Two Cities: Economic development, corporate governance and firm value in Vietnam. Research in International Business and Finance, 42 (February), 102-123. https://doi.org/10.1016/j.ribaf.2017.04.002

Cornett, MM, AJ Marcus, A. Saunders, HT (2007). The Impact of Institutional Ownership on Corporate 
Operating Performance. Journal of Banking \& Finance, 31, 1771-1794. Retrieved from (www.elsevier.com/locate/jbf)

Dalton, CM and Dalton, D.. (2005). Boards of directors: Utilizing empirical evidence in developing practical Prescriptions. British Journal of Management, 16 (1), S91-S97.

Dalton, DR, Daily, CM, Johnson, JL, \& Ellstrand, AE (1999). Number of Directors and Financial Performance: A Meta Analysis. Academy of Management Journal, 42 (6), 674-686. https://doi.org/10.2307/256988

Detthamrong, U., Chancharat, N., \& Vithessonthi, C. (2017). Corporate governance, capital structure and firm performance: Evidence from Thailand. Research in International Business and Finance, 42 (June), 689-709. https://doi.org/10.1016/j.ribaf.2017.07.011

Dung, To. Thi. (2011). CORPORATE GOVERNANCE - Empirical Research on Board Size, Board Composition, Board Activity, Ownership Concentration and Their Effects on Performance Of Listed Companies Vietnamese. Master Thesis in Business Administration University of Boras.

Fama, E. and MJ (1983). "Separation of Ownership and Control", Journal of Law and Economics, 301-325.

Firdausya, ZS, Swandari, F., \& Effendi, W. (2013). Influence Mechanism of Good Corporate Governance (GCG) in the Value of Companies (Study On The Sign Company LQ45 In Indonesia Stock Exchange). Insights Journal of Management, 1 (3), 407-424.

Forum for Corporate Governance in Indonesia (FCGI). (2001). Corporate Governance: Corporate Governance. (3rd ed.). Jakarta.

Gill, A., \& Obradovich, J. (2012). The Impact of Corporate Governance and Financial Leverage on the Value of American Firms. International Research Journal of Finance and Economics, (91), 14502887.

Ou-Yang, Hou. (2008). An Empirical Analysis of the Effect Components of the Corporate Governance Index on Firm Value: Evidence from Taiwan's Financial Industry. The Business Review, Cambridge, 10 (1), 119-128.

Harmono. (2009). Based Financial Management Balanced Scorecard (Theory Approach, Case, and Business Research). Jakarta: Earth Literacy.

Hermalin, B and Weisbach, M. (1991). The effects of board composition and durect incentives on firm performance. Financial Management, 20 (4), 101-112.

Indonesian Institute of Audit Committee. (2009). Audit Committee.

Josephine Darko, Zakaria Ali Aribi, GCU (2016). Corporate governance: the impact of director and board structure, ownership structure and corporate control on the performance of listed companies on the Ghana stock exchange. The International Journal of Business in Society, 16 (2), 259-177.

Khurram Khan, ARN and MI (2011). Impact of Corporate Governance Firms on the value of the Tobacco Industry of Pakistan. Economics, International Research Journal of Finance and Economics, (61).

Kiel, GC and Nicholson, G.. (2003). Board composition and corporate performance: How the Australian experience Informs contrasting theories of corporate governance. Corporate Governance: An International Reviews, 11 (3), 189-205.

The National Committee on Governance (NCG). (2006). Code of Good Corporate. Jakarta.

Li Lin, F. (2006). A Panel Threshold Model of Institutional Ownership and Firm Value in Taiwan. International Research Journal of Finance and Economics, (42).

Louis, JB (2004). The Audit Committee Handbook, 4th Edition.

Mak, Kusnadi, and Yuen Teen. (2005). Size Really Matters: Further Evidence on the Negative Relationship Between Board Size and Firm Value. Pacific-Basin Finance Journal.

Maug, E. (1998). Large shareholders as monitors: Is there a trade-off between liquidity and control? Journal of Finance, 53, 65-98.

Jensen,, and. Meckling (1976). Also published in Foundations of Organizational Strategy. Journal of $\begin{array}{llllll}\text { Financial } & \text { Economics, } & 3 & \text { (4), } & \text { 305-360. } & \text { Retrieved }\end{array}$ 
http://ssrn.com/abstract=94043http://hupress.harvard.edu/catalog/JENTHF.html

Navissi, F. and VN (2006). Institutional Ownership and Corporate Value. Managerial Finance, 32 (3), 247256.

Onasis, RK (2016). Influence of Corporate Governance on Firm Value in Financial Sector Companies Listed on the Stock Exchange. Economic Development, 20 (1), 1-22.

Raghunandan, K and Rama, D.. (2007). Determinants of audit committee diligence. Accounting Horizons, 21 (3), 265-279.

Rouf, MA (2011). The Relationship Between Corporate Governance and value of the Firm in Developing countres: Evidence from Bangladesh. Papilied The International Journal of Economics and Finance, 3 (5), 1-8.

Saifi, M., \& Sarafina, S. (2017). Influence Of Good Corporate Governance Financial Performance and Value (Study on State Owned Enterprises (SOEs) are Listed in Indonesia Stock Exchange Period 2012-2015). Journal of Business Administration, 50 (3), 108-117. Retrieved from https://media.neliti.com

Salvatore, D. (2011). Managerial Economics (5th ed.). Jakarta: Four Salemba.

Sembiring, ER (2006). "The characteristics of the company and disclosure of social responsibility: Empirical studies on companies listed on the Jakarta Stock Exchange. "Accounting National Symposium VIII.

Sharma, V., Naiker, V. and Lee, B. (2009). Determinants of audit committee meeting frequency: evidence from a voluntary governance system. Accounting Horizons, 23 (3), 245-263.

Shleifer, AARV (1986). Large Shareholders And Corporate Control. Journal of Political Economics, 461488.

Siallagan Hamonangan, MM (2006). Mechanism of Corporate Governance, Earnings Quality and Value. Accounting National Symposium IX, (061), 23-26. Retrieved from https://alternativeto.net/software/maltego/

Slovin, MB, \& Sushka, ME (2007). Ownership Concentration, Corporate Control Activity, and Firm Value: Evidence Ownership Concentration, Corporate Control Activity, and Firm Value: Evidence from the Death of Inside blockholders. The Journal of Finance, 48 (4), 1293-1321.

Syafitri, T., Nuzula, NF, \& Nurlaily, F. (2018). Influence Of Good Corporate Governance Company Values (Study on Industrial Company Metals and Allied Sector Sub Listed on the Stock Exchange Period 2012-2016). Journal of Business Administration (JAB), 56 (1), 118-126.

Tornyeva, K. and WT (2012). Corporate Governance and Firm Performance: Evidence from the Insurance Sector of Ghana. European Journal of Business and Management, 4 (13), 95-113.

Veronica, S. and BSY (2005). Corporate Governance, Information asymmetry, and Earnings Management. Journal of Accounting and Finance Indonesia, 2 (1), 1-30. 